\title{
Early pregnancy failure as seen during the course of equine stud farm practice in Newmarket, 1996-2003
}

\author{
Sidney W. Ricketts \\ Rossdale and Partners, Beaufort Cottage Laboratories, High Street, Newmarket, UK.
}

\begin{abstract}
Summary
A retrospective survey was undertaken of the records of 80 mares for which the diagnosis of early pregnancy failure (EPF) was made by the author on the basis of repeated ultrasound scan examination from 14 to 65 days after last mating during the course of routine equine stud farm practice in Newmarket over the last eight years. This revealed an overall incidence of $6.5 \%$ of the pregnancies diagnosed. Nearly $50 \%$ of cases presented as absence of a conceptus, where one had been diagnosed before, with no other sign of ultrasonic abnormality. There was no clear association with mare age or breeding status. Endometrial cytological and bacteriological results were reviewed for examinations made of these mares at the time of their EPF or at their subsequent oestrous period, revealing that in only $4 \%$ ( 3 mares) was there evidence of significant acute endometritis. These mares presented with signs of collapsing conceptus, fragmentation and turbid fluid formation. It is therefore postulated that the majority of these losses may have been associated with genetic, developmental or functional abnormalities. $64 \%$ of the mares that suffered EPF ended that season pregnant again and/or produced a live foal the following year.
\end{abstract}

Keywords: Equine Early Pregnancy Failure

\begin{abstract}
Beobachtungen zum embryonalen Fruchttod bei Stuten in der Gestütsbetreuung in Newmarket, 1996-2003
Im Rahmen einer retrospektiven Studie aus den letzten acht Jahren der Gestütsbetreuung in Newmarket wurden 80 Stuten mit einem embryonalen Fruchttod (EFT) untersucht. Die Diagnosen wurden von dem Autor auf Grund routinemäßig wiederholter ultrasonographischer Untersuchungen 14 bis 65 Tage nach der letzten Belegung gestellt. Der Anteil der EFT betrug 6,5\% aller diagnostizierten Trächtigkeiten. In ca. 50\% der Fälle, in denen kein Embryo mehr nachgewiesen werden konnte, obwohl zuvor eine Frucht beobachtet wurde, wiesen keine weiteren ultrasonographischen Veränderungen auf. Eine Korrelation zu dem Alter oder dem Reproduktionsstatus der Stuten konnte nicht festgestellt werden. Die Ergebnisse der endometrialen Zytologie und Bakteriologie zum Zeitpunkt des EFT und des folgenden Zyklus zeigten, dass lediglich bei 4\% (3 Stuten) eine akute Endometritis vorlag. Diese Stuten zeigten Anzeichen eines zerfallenden Konzeptus und gekörnt erscheinender trüber Flüssigkeit. Daher wird vermutet, dass die Mehrzahl der EFT auf Grund genetischer Defekte oder funktioneller bzw. entwicklungsbedingter Abnormalitäten statt fanden. 64\% der Stuten mit einem EFT wurden im Verlauf der gleichen Saison tragend und/oder brachten in der folgenden Saison ein lebendes Fohlen zur Welt.
\end{abstract}

Schlüsselwörter: Reproduktion, Equiner embryonaler Frühtod

\section{Introduction}

The Thoroughbred horse breeding industry recognises that early pregnancy failure (EPF) remains a significant cause of wastage. Accurate incidence and aetiology data is not readily available.

An analysis of Weatherbys' Annual Returns for UK and Irish Thoroughbred mares shows that the percentage of mares (25.271 mares registered in 2002) recorded as failing to produce a live foal after being diagnosed pregnant at 40-50 Days (not associated with detected abortion) was 1.9\% in 1977 as compared to $2.1 \%$ in 2002 (Fig. 1). Although the data is subject to reporting inaccuracies and is skewed through the 1990s by the introduction and increasing use of ultrasound scanning, which made the accurate diagnosis of early pregnancy failures possible, current rates of EPF appear to be almost identical to those recorded two decades previously. In comparison, during the period 1997 to 2002, conception and live foal rates have risen from $77.5 \%$ to $89.4 \%$ and from $68.1 \%$ to $81.3 \%$, and barren mare rates have fal- len from $22.5 \%$ to $10.6 \%$ (Ricketts unpublished data), in most encouraging manners. The Thoroughbred breeding industry requires further progress to be made to help minimise EPF.

Weatherbys' data clearly understate the incidence of EPF for a number of reasons in addition to reporting inaccuracies. Losses that occur before 40 days are not recorded as EPF because Weatherbys' definition requires a positive pregnancy diagnosis at 40 days. Mares who suffer EPF prior to endometrial cup formation (approximately 35 Days) usually return to oestrus and may conceive again and then produce a live foal the following year so are returned to Weatherbys as having produced a live foal. Those who suffer EPF prior to 35 days late in the season and are not re-mated for commercial or logistic reasons will be recorded as 'barren'.

Ball (1988, 1993) states that the detected incidence of embryonic death varies depending on method of determination, interval of detection and group of animals under study. He reports that most investigators have detected embryonic death rates of between $5 \%$ and $24 \%$ in fertile mares and hig- 
her in subfertile mares. Ginther (1995) reports that in normal mares, the loss rate from Days 11 to 40 ranges from $1.1 \%$ to $2.1 \%$. He reports that loss rates between Days 11 and 15 is $1.3 \%$ for normal mares but was $18.2 \%$ for a herd with a lar-

Fig 1 Weatherbys' Annual Returns for UK and Irish Thoroughbred Mares. Early pregnancy failures (mares who fail to produce a live foal after being diagnosed pregnant at 40-50 days and not associated with detected abortion) as the percentage of mares mated by registered TB stallions (minus mares who died, were exported or for whom no returns were made)

Jährlicher Gesundheitsreport für die Warmblutstuten in England und Irland. Embryonaler Fruchttod (Stuten, die kein lebendes Fohlen zur Welt brachten, nachdem eine Trächtigkeit am 40. bis 50. Tag festgestellt worden war und bei denen kein Abort beobachtet wurde) als Prozentsatz der Stuten, die durch registrierte Warmbluthengste belegt wurden (abzüglich der Stuten, die starben, exportiert wurden oder von denen keine Rückantworten vorliegen)

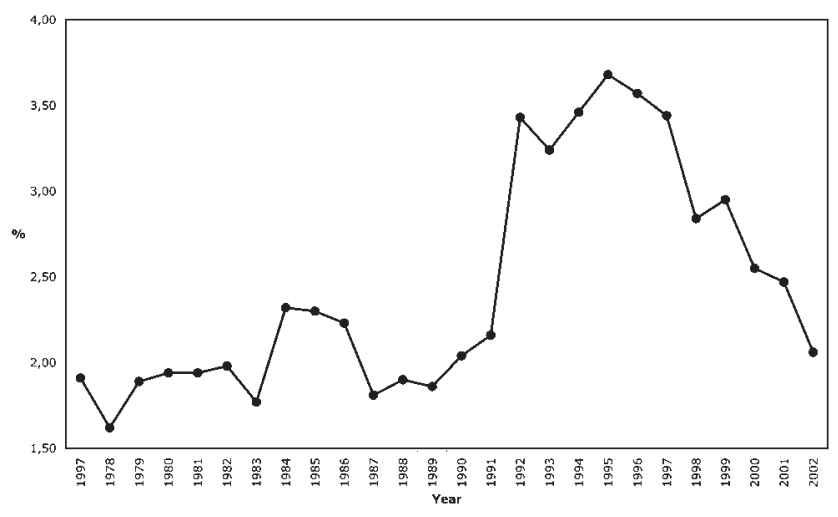

ge proportion of subfertile mares (this included mares with dioestrous uterine fluid collections, short oestrous cycles, early embryonic loss or failure to establish pregnancies the previous year).

Morris and Allen (2002) surveyed the reproductive efficiency of 1393 Thoroughbred mares visiting 22 stud farms in Newmarket during the 1998 breeding season. They found that $17.3 \%$ of pregnancies diagnosed at around Day 15 after ovulation subsequently failed, the majority (59.7\%) of these losses occurring between Days 13 and 35. They found that mares of 3-8 years of age lost fewer pregnancies between Days 15 and 35 than did older mares and that maiden mares lost fewer pregnancies at this stage than did foaling mares. They found that more pregnancies were lost between Days 15 and 35 in mares mated at their first post-partum oestrus ('foal heat $^{\prime}$ ).

Equine gynaecologists can now diagnose pregnancy as early as 10-14 days with currently available ultrasound scanning equipment and can therefore diagnose EPF on the basis of loss of a conceptus following a previously positive diagnosis. Diagnosis of EPF is most commonly based upon:-

1. No ultrasonic evidence of a conceptus following a pre vious positive examination with no sign of uterine abnormality.

2. Ultrasonic evidence confirming the progressive loss of an abnormal conceptus, with signs of small-for-dates/failure to grow conceptus (Fig. 2), endometrial oedema, clear or turbid uterine fluid accumulation (Fig. 3), or signs of conceptual collapse (Fig. 4), or membrane separation (Fig. 5).
3. Ultrasonic evidence of a dead (no signs of heart beat) (Fig.6) or abnormal (slow heart beat) foetus (Fig.7).

4. Ultrasonic evidence of failure of the foetus to develop.

Once conceptual abnormality and/or a dead foetus is diagnosed and confirmed by repeated examination, therapeutic steps are taken to terminate the failing pregnancy (uterine evacuation by repeated uterine flush with sterile saline solution), to return the mare to oestrus (administration of prostaglandins) and to re-examine her for suitability for remating on the basis of endometrial cytological and bacterio-

Fig 2 Ultrasound scan print-out of a small-for-dates 16 Day conceptus which subsequently did not survive

Ultraschallbild eines 16 Tage alten Konzeptus, der für diesen Zeitpunkt zu klein ist und im weiteren Verlauf nicht überlebte
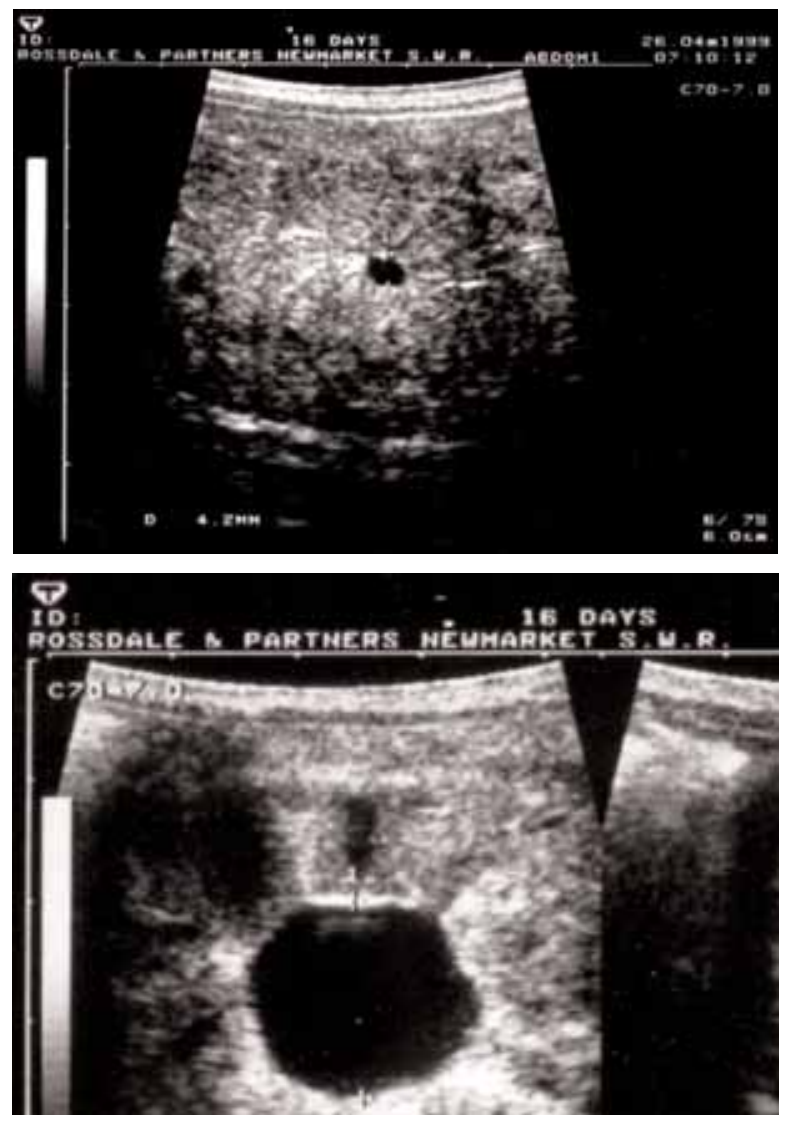

Fig 3 Ultrasound scan print-out of a collapsing 16 Day conceptus with adjacent endometrial oedema and turbid uterine fluids Ultraschallbild eines zerfallenden Konzeptus mit endometrialem Ödem und trübem Fruchtwasser

logical examinations (Wingfield Digby and Ricketts 1982, Ricketts and Mackintosh 1987).

Whilst surveys of the cases of equine abortion based upon necropsy examination evidence have been published (Ricketts et al. 2001), the primary causes of EPFs are often not diagnosed with certainty because the foetus and placental membranes are seldom recovered for satisfactory pathological investigations. Ball $(1988,1993)$ states that embryonic death may be associated with maternal and/or external factors. Under maternal factors he includes endocrine factors, oviduct, uterus, maternal age and lactation/foal heat breeding. Under external factors he includes stress, seasonal factors, sire effects and iatrogenic factors. It is well recognised that because of equine cervical physiological (relaxation of the 
cervix during oestrus) and coital (intra-cervical/uterine ejaculation) considerations, endometritis is a common gynaecologic hazard for broodmares and is an important cause of conception and pregnancy failures. Morris and Allen (2002) suggested that the increased early pregnancy failure rate seen in older mares in their survey may have been associated with progressive degenerative changes in the endometrium and susceptibility to uterine infection.

The aim of this survey was to determine the incidence and clinical presentation of EPF diagnosed by the author under conditions of routine Thoroughbred stud farm practice in New-

Fig 4 Ultrasound scan print-out of a collapsing 35 Day conceptus with fragmentation and turbid foetal fluids

Ultraschallbild eines zerfallenden 35 Tage alten Konzeptus mit gekörnt erscheinendem trübem Fruchtwasser
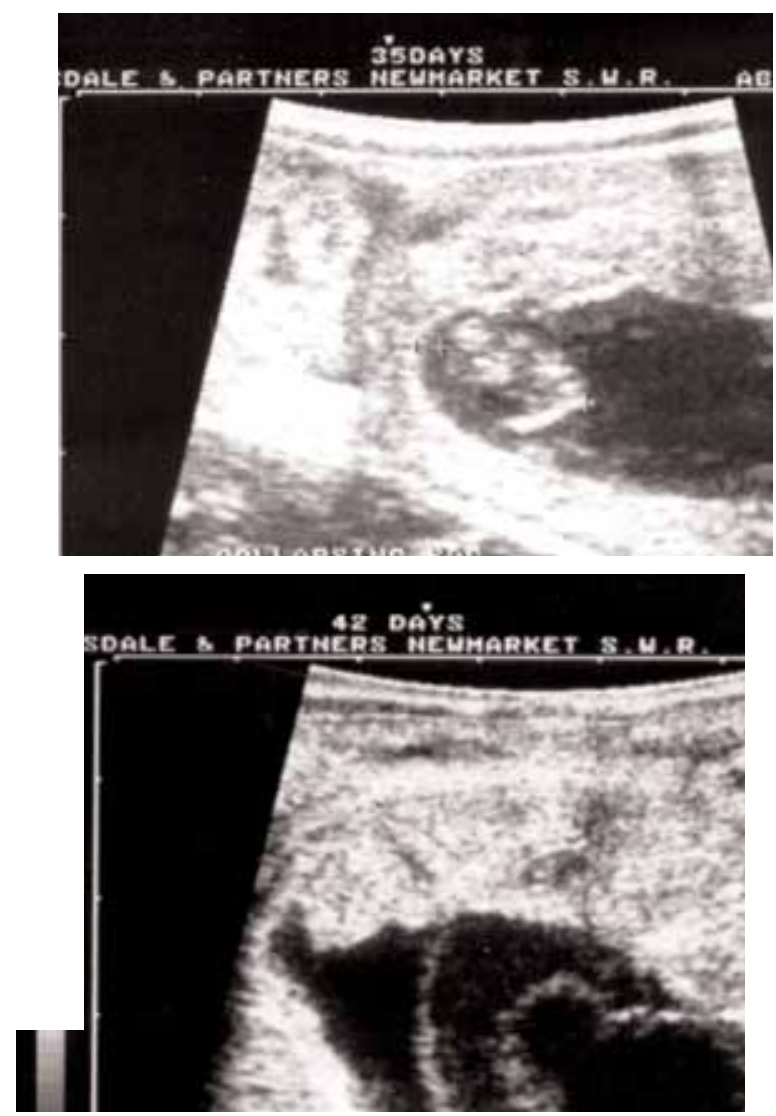

Fig 5 Ultrasound scan print-out of a 42 Day collapsing conceptus with separating membranes and a dead foetus

Ultraschallbild eines 42 Tage alten toten Konzeptus mit Separation der Membranen

market and what percentage of these losses were associated with cytological evidence of endometritis.

\section{Materials and Methods}

The records of the author's routine ultrasound scan examinations at multiple stud farms in the Newmarket area, from 1996-2003, were retrospectively reviewed. Depending upon managerial considerations, particularly individual stud farm and mare owner policies, mares were usually examined for the first time between 14 and 17 days after last mating, for the second time between 18 and 23 days, for the third time between 24 and 30 days, for the fourth time between 31 and 50 days and for the fifth time between 51 and 65 days after last mating. When EPF was first suspected or diagnosed, the mare was re-examined, if necessary, daily or every other day until the diagnosis was conclusively confirmed. Steps were then taken to evacuate the uterus, to treat any cases of endometritis and to prepare the mare for mating again, if appropriate. Very few mares in this series were mated during the first post-partum oestrus ('foal heat').

Each diagnosis of early pregnancy failure was investigated in terms of the results of endometrial swab/smear or wash (cytological and bacteriological, Wingfield Digby and Ricketts 1982, Ricketts and Mackintosh 1987) for each mare at the

Fig 6 Ultrasound scan print-out of a 42 Day dead foetus (in real time had no demonstrable heartbeat)

Ultraschallbild eines 42 Tage alten toten Konzeptus (es war kein Herzschlag nachweisbar)
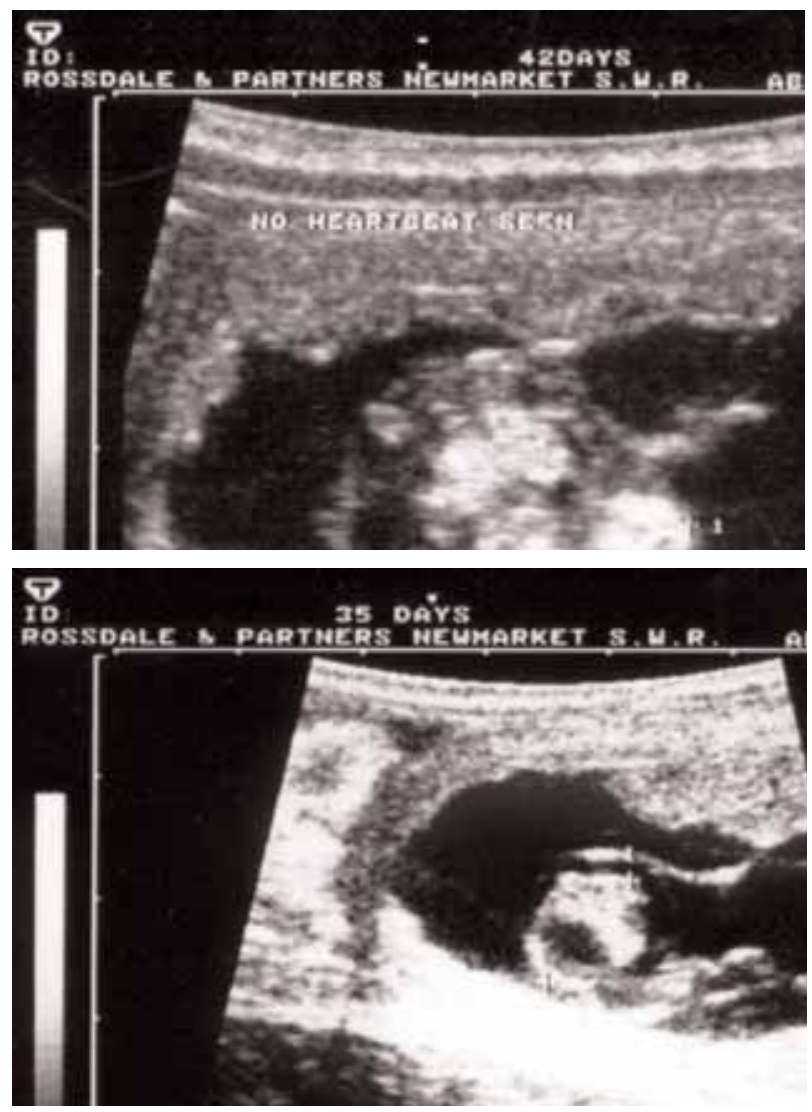

Fig 7 Ultrasound scan print-out of a 42 Day dying abnormal foetus (in real time had a slow heartbeat and there are signs of foetal cavitation/'cystic' abnormality)

Ultraschallbild eines 42 Tage alten sterbenden abnormalen Fetus (Es war enein langsamer Herzschlag und Anzeichen fetaler Spaltbildung und zystischer Abnormalitäten zu erkennen)

time of her conceptual loss (if in oestrus or if and when an abnormal conceptus was flushed from her uterus) or at her next natural or prostaglandin-induced oestrous period, when cervical relaxation occurred. Significant acute endometritis was diagnosed on the basis of finding more than $0.5-5 \%$ polymorphonuclear leukocytes (PMNs) as a proportion of the cells seen on a Pollack's trichrome stained smear (Ricketts and Mackintosh 1987).

The final breeding performance for each mare for the mating season in which her EPF was diagnosed was investigated from Weatherbys' Returns for Mares for the following year or by 
direct enquiry. For 2003 mares the mare's pregnancy status at the end of the breeding season (July) was recorded.

\section{Results}

During 5906 ultrasound scan examinations (from 14 to 65 days after last mating) of 1232 pregnancies, 80 cases of EPF were diagnosed from 72 mares $(8$ mares suffered repeated failures) (Tab. 1). 6.5\% of the pregnancies diagnosed therefore suffered EPF between 14 and 65 days after last mating. Annual EPFs as a percentage of pregnancies diagnosed ranged from $4.6 \%$ in 2003 to $10.4 \%$ in 2002 .

The mares' ages ranged from 3 to 22 years with an average of 9.7 years (Fig.8). At the time of the EPFs, 53 (66\%) were mares with foals-at-foot, 15 (19\%) were mares that were barren following the previous mating season and 12 (15\%) were

Tab 1 Numbers of mare ultrasound scan examinations, pregnancies and EPFs, 1996-2003

Anzahl durchgeführter Ultraschalluntersuchungen, festgestellte Trächtigkeiten und nachgewiesener embryonaler Frühverluste bei Stuten von 1996-2003

\begin{tabular}{|c|c|c|c|c|}
\hline Year & Examinations & Pregnancies & EPFs & \% Pregnancies \\
\hline & & 144 & 12 & $8.3 \%$ \\
\hline 1996 & 644 & 144 & 9 & $6.4 \%$ \\
\hline 1997 & 634 & 140 & 9 & $6.6 \%$ \\
\hline 1998 & 659 & 137 & 6 & $4.4 \%$ \\
\hline 1999 & 669 & 137 & 10 & $7.6 \%$ \\
\hline 2000 & 608 & 132 & 8 & $4.4 \%$ \\
\hline 2001 & 861 & 181 & 17 & $10.4 \%$ \\
\hline 2002 & 833 & 164 & 9 & $4.6 \%$ \\
\hline 2003 & 998 & 197 & & $6.5 \%$ \\
\hline & & & 80 & \\
\hline $1996-2003$ & 5,906 & 1,232 & &
\end{tabular}

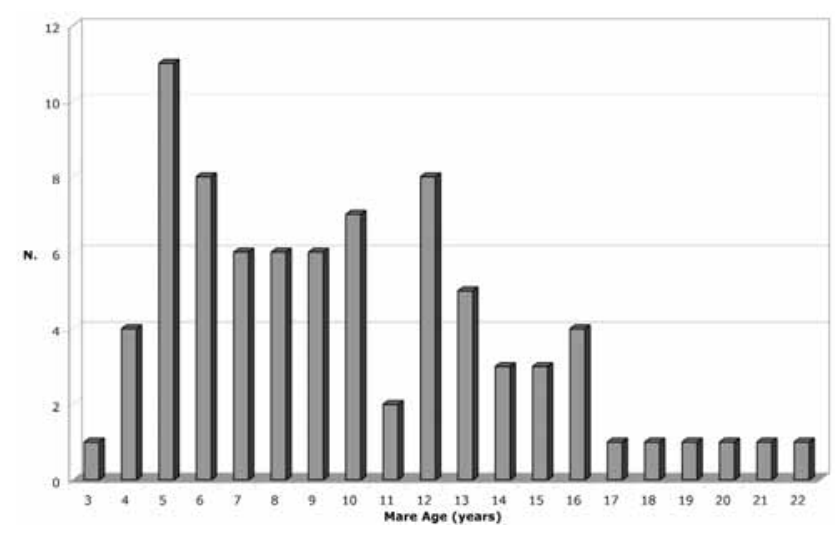

Fig 8 Age (frequency) of mares at diagnosis of EPF Altersverteilung der Stuten mit embryonalem Fruchttod

maiden mares (in their first mating season after retiring from racing) (Tab. 2). Eight (10\%) of EPFs were first diagnosed at first examination between 14 and 17 days (Fig.9). 14 (18\%) were first diagnosed at second examination between 18 and 23 days. 36 (45\%) were first diagnosed at third examination between 24 and 30 days. 21 (26\%) were first diagnosed at fourth examination between 31 and 50 days. Only one (1\%) EPF was first diagnosed at fifth examination between 51 and 65 days (63 days) after last mating.

Of the 80 cases of EPF, 39 (49\%) presented as no ultrasonographic sign of a conceptus following a previously positive diagnosis, i.e. loss of conceptus (Tab. 3). 17 (21\%) presented as signs of a collapsing conceptus with fragmentation and turbid fluid formation (Fig.4), sometimes with signs of membrane separation (Fig.5). 10 (12\%) presented as a small-fordates conceptus which, on subsequent examination(s), sho- wed no signs of growth and/or signs of collapse. 6 (8\%) presented as a small-for-dates sac which, on subsequent examination(s), did not develop a foetus and eventually collapsed. $6(8 \%)$ presented as an otherwise apparently normal conceptus but with a foetus in which the heartbeat was not detectable (Fig. 6) or appeared slow (Fig.7). 2 (2\%) presented as an otherwise apparently normal conceptus but with focally adjacent endometrial oedema, repeated examinations confirming pregnancy failure.

Of the 80 cases of EPF, only $3(4 \%)$ showed cytological evidence of acute endometritis (>0.5-5\% PMNs) in uterine flush or endometrial smear samples taken at the time of diagnosis or at the next oestrus. Of these three cases of acute endometritis, bacteriological culture examinations revealed a growth of Streptococcus zooepidemicus in one case, a growth of Enterococcus faecalis in another case and no aerobic or microaerophilic growth in the third case.

Of the 80 cases of EPF, 51 (64\%) produced a live foal the following year or (in the 2003 cases) were pregnant again at the end of the season (Table 4). Four (5\%) cases ended the sea-

Tab 2 Breeding status of EPF mares at the time of diagnosis Reproduktionsstatus der Stuten mit embryonalen Frühtod zum Zeitpunkt der Diagnose

\begin{tabular}{|c|c|c|}
\hline Mare status at diagnosis of EPF & N. & $\%$ \\
\hline Foal-at-foot (foaled earlier this season) & 53 & 66 \\
\hline Maiden (15t season at stud) & 15 & 19 \\
\hline Tarren (mated the previous season but did not conceive) & 12 & 15 \\
\hline Total & & \\
\hline & 80 & 100 \\
\hline
\end{tabular}

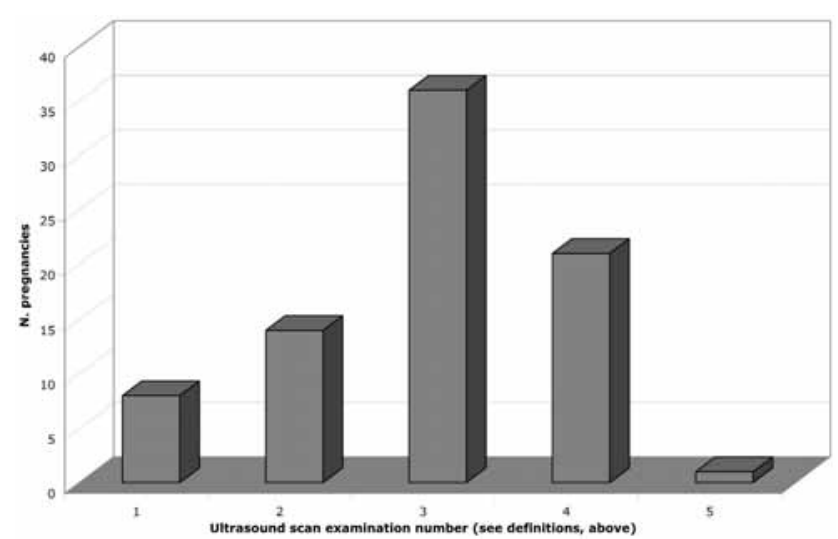

Fig 9 Stage of first diagnosis of EPF ( $1^{\text {st }}$ scan at $14-17$ days, $2^{\text {nd }}$ scan at 18-23 days, $3^{\text {rd }}$ scan at 24-30 days, $4^{\text {th }}$ scan at 31-50 days, $5^{\text {th }}$ scan at 51-65 days after last mating)

Stadium des embryonalen Fruchttodes zum Zeitpunkt der ersten Diagnose (1. Untersuchung 14-17 Tage, 2. Untersuchung 18-23 Tage, 3. Untersuchung 24-30 Tage, 4. Untersuchung 37-50 Tage, 5. Untersuchung 51-65 Tage nach der letzten Belegung)

son pregnant but aborted later that year or during the next year. $17(21 \%)$ cases were not in foal at the end of the season (barren) and $9(11 \%)$ cases involved mares that suffered EPF late in the season and were not mated again for managerial reasons.

\section{Discussion}

This survey was of detailed ultrasound scan examination records of a population of Thoroughbred mares visiting some commercial stud farms in Newmarket. The data included no 
recognised cases of Mare Reproductive Loss Syndrome (MRLS) (Morehead et al. 2002, Dwyer et al. 2003). This condition has not yet been diagnosed in Newmarket. The overall incidence of EPF occurring between 14 and 65 days after last mating was $6.5 \%$ of the pregnancies diagnosed (Tab. 1). The annual incidence varied from $4.4 \%$ to $10.4 \%$. Morris and Allen (2002) recorded 10.4\% losses between Days 15 and 35 in their survey. Eight mares suffered two EPFs during this survey, seven of which involved two EPFs during consecutive pregnancies. This survey involved both 'normal' and 'subfertile' mares and therefore it is not surprising that the recorded incidence falls between the two incidences quoted by Ginther (1995).

The age (average, 9.7 years, range 3-22 years) (Fig.8) and breeding status (6\% foaling, 19\% barren and $15 \%$ maiden) (Tab. 2) of the mares when the diagnosis of EPF was made reflects the population of the mares in the survey group and so this survey shows no obvious association between mare

Tab 3 Ultrasonographic presentation of EPF at time of diagnosis

Ultrasonographische Darstellung des embryonalen Frühtodes zum Zeitpunkt der Diagnose

\begin{tabular}{|c|c|c|}
\hline Ultrasonographic appearance & N. & $\%$ \\
\hline No sign of conceptus following previous positive diagnosis & 39 & 49 \\
\hline Collapsing conceptus with fragments and turbid fluid & 17 & 21 \\
\hline Small-for-dates conceptus & 10 & 12 \\
\hline Failure of foetus to develop & 6 & 8 \\
\hline Foetus with no detectable or slow heartbeat & 6 & 8 \\
\hline Endometrial oedema adjacent to conceptus & 2 & 2 \\
\hline Total & & \\
\hline
\end{tabular}

\begin{tabular}{|c|c|c|}
\hline Mare status at the end of the mating season & N. & $\%$ \\
\hline Live foal the following year (pregnant, 2003) & 51 & 64 \\
\hline Aborted after the season & 3 & 4 \\
\hline Barren (mated again but did not conceive) & 17 & 21 \\
\hline Not mated again because too late in season & 9 & 11 \\
\hline Total & 80 & 100 \\
\hline
\end{tabular}

Tab 4 Breeding performance of EPF mares at the conclusion of the mating season

Zuchterfolg bei den Stuten mit embryonalem Fruchttod am Ende der Zuchtsaison

age nor breeding status. This is in variance with the findings of Morris and Allen (2002). The age frequency chart (Fig.8) shows a bias towards mares of 5 and 6 years rather than older mares, again reflecting the age of the mare population surveyed. Therefore in this survey there was no demonstrable association with developing chronic endometrial degenerative disease (endometrosis) (Ricketts and Alonso 1991b). The majority of this mare population was positively managed with the aim of preparing barren mares for the season with a programme of gynaecological examinations, indicated treatments and follow-up examinations during the previous autumn to try to delay the inevitable advance of chronic endometrial degenerative disease (Ricketts and Alonso 1991a). Mares with lymphatic endometrial cysts (Ricketts 1987) did not appear prone to EFD.

$49 \%$ of the cases of EPF in this survey presented as a negative ultrasound scan examination following a previous positive (Tab. 3). It is not know whether the concepti were lost through the cervix or collapsed and were resorbed in-utero between examinations. $12 \%$ presented as small-for-dates and did not progress, $8 \%$ presented as failure of the foetus to develop,
$8 \%$ presented as a dead or bradycardic foetus and $2 \%$ presented as focal endometrial oedema adjacent to the conceptus. None of these cases showed signs of acute endometritis and therefore presumably genetic, developmental or functional factors were involved. $21 \%$ presented as signs of a collapsing conceptus with fragmentation, turbid fluid formation and sometimes membrane separation. Acute endometritis was associated with 3 of these 17 mares.

Only $3(4 \%)$ of the cases of EPF in this survey were associated with demonstrable cytological evidence of acute endometritis. This is not thought to be an underestimate because of delayed cervical relaxation delaying the collection of endometrial swabs and smears and/or uterine flushes for laboratory examination. Where acute endometritis is involved, this usually results in signs of a collapsing conceptus with fragmentation, turbid fluid formation and sometimes membrane separation, which can be recognised during ultrasound scan examination and endometritis usually causes premature luteolysis followed by cervical relaxation, allowing samples to be collected without significant delay. None of the eight mares that suffered two EPFs during this survey, seven of which involved two EPFs during consecutive pregnancies were suffering from demonstrable acute endometritis. This mare population was positively managed with the aim of preventing acute endometritis, with the use of endometrial cytological and bacteriological screening prior to each mated oestrus (Wingfield Digby and Ricketts 1982, Ricketts and Mackintosh 1987).

$45 \%$ of the EPFs were diagnosed at the third ultrasound scan examination made between 24 and 30 days after last mating (Fig.8). 26\% were diagnosed at the fourth examination between 31 and 50 days, $18 \%$ at the second examination between 18 and 23 days, $10 \%$ at the first examination between 14 and 17 days and only 1 mare at her fifth examination at 63 days after last mating. In fact 72 (90\%) of the 80 EPF diagnoses were made at or prior to 40 days after last mating, i.e. before endometrial cup formation would prevent the mare from being returned to oestrus and prepared for mating again. Of the 80 cases of EPF, 51 (64\%) produced a live foal the following year or (in the 2003 cases) were pregnant again at the end of the season (Tab. 4).

\section{Conclusions}

In this population of mares, who were positively managed to prevent acute endometritis and to delay the development of chronic endometrial degenerative disease, the incidence of EPF between 14 and 65 days after last mating was 6.5\% of the pregnancies diagnosed. MRLS was not involved and only $4 \%$ of losses were associated with acute endometritis, all of which presented with ultrasonic evidence of a collapsing conceptus with fragmentation and turbid fluid formation. Nearly $50 \%$ of cases presented as absence of a conceptus, where one had been diagnosed before, with no other sign of ultrasonic abnormality. In this survey, EPF did not appear to have been associated with mare age nor breeding status and therefore the development of chronic endometrial degenerative disease. One must therefore postulate that the majority of these losses may have been associated with genetic, developmental or functional abnormalities. Proving this is hampered by the fact that the products of pregnancy failure are seldom retrievable for diagnostic examination. It is interesting 
that 14 EPFs, which involved 7 mares that suffered a second EPF at the following pregnancy, were not associated with demonstrable acute endometritis so may have involved repeated genetic, developmental or functional abnormalities.

A policy of preventive management of mares for endometritis and chronic endometrial degenerative disease is considered important for maintaining low incidence of EPF. This includes the detailed assessment of each mare's uterus prior to each mating with manual palpation, ultrasound imaging, endometrial cytological and bacteriological screening, and the targeted use of post-mating uterine treatments. During the autumn this includes detailed gynaecological assessments, indicated treatments and follow-up examinations for barren and rested mares.

The majority of cases (90\%) of EPF in this survey occurred at gestational stages prior to endometrial cup formation, allowing most mares to be mated again. A managerial policy of routine serial ultrasound scan examinations of mares during early pregnancy will allow early diagnoses of EPF to be made, allowing the majority of cases to be re-mated with more than a $50 \%$ chance of producing a live foal the following year.

\section{Literature}

Ball B. A. (1988): Embryonic loss in mares: incidence, possible causes and diagnostic considerations. Vet. Clin. N. Am.: Equine Practice, 4, 263290

Ball B. A. (1993): Embryonic death in mares. In Equine Reproduction, Ed. A.O. McKinnon and J.L. Voss, Lea and Febiger, 517-531

Dwyer R. M., Garber L. P., Traub-Dargatz J. L., Meade B. J., Powell D., Pavlick M. P. and Kane A. J. (2003): Case-control study of factors associated with excessive proportions of early fetal losses associated with mare reproductive loss syndrome in central Kentucky during 2001. J. Am. Vet. Med. Assoc. 222, 613-619
Ginther O. J. (1995): Embryonic Loss. In Ultrasonic Imaging and Animal Reproduction: Horses, Book 2, 175-197

Morehead J. P., Blanchard T. L., Thompson J. A. and Brinsko S. P. (2002): Evaluation of early fetal losses on four equine farms in central Kentukky: 73 cases (2001). J. Am. Vet. Med. Assoc. 220, 1828-1830

Morris L. H. A. and Allen W. R. (2002): Reproductive efficiency of intensively managed Thoroughbred mares in Newmarket. Equine Vet. J., 34, 51-60

Ricketts S. W. (1987): Uterine abnormalities. In: Current Therapy in Equine Medicine, 2nd Edit., Ed. N.E. Robinson, W.B. Saunders Co., $503-$ 505

Ricketts S. W. and Alonso S. (1991a): Assessment of the breeding prognosis of mares using paired endometrial biopsy techniques. Equine Vet. J. 23, 185-188

Ricketts S. W. and Alonso S. (1991 b): The effect of age and parity on the development of equine chronic endometrial disease. Equine Vet. J. 23, 189-192

Ricketts S. W. and Mackintosh M. E. (1987): The role of anaerobic bacteria in equine endometritis. J. Reprod. Fertil. Supplement 35, 343351

Ricketts S. W., Barrelet A. and Whitwell K. E. (2001): A review of the causes of abortion in UK mares and means of diagnosis used in an equine studfarm practice in Newmarket. Pferdeheilkunde 17, 589-592

Wingfield Digby N. J. and Ricketts S. W. (1982): Results of concurrent bacteriological and cytological examinations of the endometrium of mares in routine studfarm practice 1978-81. J. Reprod. Fertil. Supplement 32, $181-185$

Professor Sidney W. Ricketts

Beaufort Cottage Laboratories

High Street, Newmarket, Suffolk CB8 8JS, UK

sidney.ricketts@rossdales.com 